\title{
MEMBANDINGKAN EFISIENSI PEMBIAYAAN BANK UMUM SYARIAH DAN BANK UMUM KONVENSIONAL DI INDONESIA DENGAN METODE DATA ENVELOPMENT ANALYSIS (DEA) ")
}

\author{
Ditta Feicyllia Sari \\ Mahasiswa Program Studi S1 Ekonomi Islam-Fakultas Ekonomi dan Bisnis-Universitas Airlangga \\ Email: feicylliaditta@gmail.com \\ Noven Suprayogi \\ Departemen Ekonomi Syariah-Fakultas Ekonomi dan Bisnis-Universitas Airlangga \\ Email: noven2005@gmail.com
}

\begin{abstract}
:
This study aims to determine and comparing the level of financing efficiency of Islamic Banks and Conventional Bank in Indonesia. This study uses a quantitative non-parametric approach With Data Envelopment Analysis (DEA) VRS assumption, and a statistical tool Mann-Whitney U-Test. The samples are 10 Islamic Banks and 13 Conventional Commercial Bank those comply with the specified sample criteria. During 2010 to 2014, Islamic Bank has efficiency level of financing relatively higher than Conventional Bank based on VRS assumption. Source of inefficiency in Islamic Banks finance more due to inefficiency on a scale of financing. While the hypothesis test showed there are significant differences in the level of scale financing efficiency, and no significant difference in the level of financing efficiency between Islamic Banks and Conventional Banks in Indonesia with CRS and VRS assumption.
\end{abstract}

Keywords: Data Envelopment Analysis (DEA), Efficiency, Pure Technical Efficiency (VRS).

\section{PENDAHULUAN}

\section{Latar Belakang}

Perkembangan perbankan Syariah di Indonesia menjadi demikian pesatnya sejak didirikannya Bank Umum Syariah pertama di Indonesia pada tahun 1992. Dari segi kelembagaan, hingga Juni 2014 tercatat ada 11 Bank Umum Syariah, 23 Unit Usaha Syariah, dan 163 BPRS dengan total jaringan kantor sejumlah 2.582 kantor yang tersebar di seluruh Indonesia. Indonesia (Sumber

http:/www.ojk.go.id/statistik-perbankan-

Syariah-november-2014, diakses pada tanggal 22 Januari 2015). Namun dengan perkembangan yang pesat dari segi kelembagaan tidak menjadikan pertumbuhan operasional Bank Syariah dengan fungsi utama sebagai lembaga intermediary menjadi bebas hambatan.

Dari segi pendanaan, Bank Syariah dihadapkan pada tantangan terbatasnya daya saing dalam mendapatkan Dana Pihak Ketiga (DPK) yang "murah" dan berjangka waktu relatif panjang. (Sumber: http:/www.ojk.go.id/laporanperkembangan-keuangan-Syariah-2013, diakses pada tanggal 31 Maret 2015). Dari segi pembiayaan, Bank Syariah dihadapkan pada tantangan sulitnya memperluas pangsa pasar. Hal ini dikarenakan masyarakat menilai bahwa tingkat margin/fee/bagi hasil yang ditetapkan oleh Bank Syariah kepada nasabah pembiayaan lebih mahal bila dibandingkan dengan tingkat bunga yang ditetapkan oleh bank konvensional

1) Jurnal ini merupakan bagian dari skripsi yang ditulis oleh Ditta Feicyllia Sari 041114033 yang diuji pada tanggal 7 Agustus 2015 
(http:/www.m.detik.com/finance/read/20 14/11/05, diakses pada tanggal 1 April 2015).

Berdasarkan fakta tersebut di atas, maka penelitian ini akan difokuskan pada topik manajemen pembiayaan Bank Umum Syariah yang efektif dan efisien. Manajemen pembiayaan dan pendanaan yang efektif dan efisien akan memberikan keunggulan kompetitif bagi Bank Syariah.

Konsep efisiensi memang merupakan salah satu prinsip yang sangat penting dalam bisnis. Dari sudut pandang ekonomi islam, setiap muslim dalam menjalankan bisnisnya haruslah memiliki keinginan yang kuat untuk meningkatkan efisiensi, yaitu dengan mengurangi biaya demi kebaikan konsumennya (Affandi (2002) dalam Kamaruddin,et.al 2008:33) ). Konsep efisiensi ini sejalan dengan prinsip Syariah yang bertujuan untuk mencapai dan menjaga maqashid Syariah yaitu terpeliharanya al-maal (Kamaruddin,et.al 2008:33). Konsep ini sebagaimana terkandung dalam Al-Qur'an Surat AlIsraa' (17) ayat 26-27:

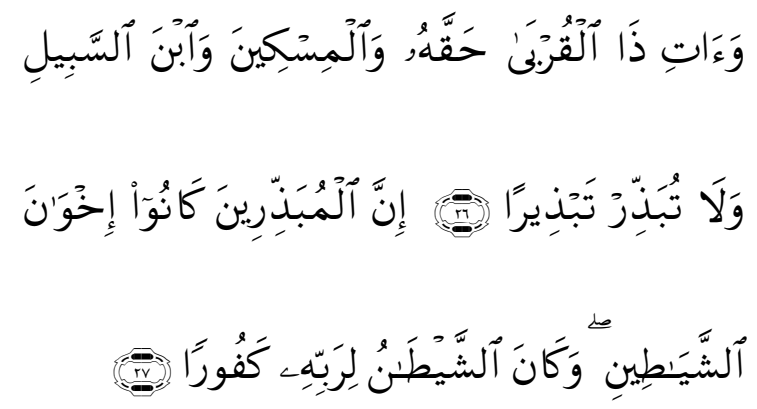

Wa'āti-żalqurbā haqqahu walmiskīna wabnassabili walā tubażir tabżirāa 'innalmubażirīna-kā nū

'ikhwānasysyayā țānu-lirabbihi kafūrā Artinya: dan berikanlah kepada keluarga-keluarga yang dekat akan haknya, kepada orang miskin dan orang yang dalam perjalanan dan janganlah kamu menghamburhamburkan (hartamu) secara boros. Sesungguhnya pemboros-pemboros itu adalah saudara-saudara syaitan dan syaitan itu adalah sangat ingkar kepada Tuhannya (QS.Al-Israa (17):2627).

Definisi efisiensi itu sendiri secara umum menurut Martic et.al (2009:37), adalah kemampuan suatu unit bisnis untuk mencapai target bisnis dengan menggunakan seminimal mungkin sumber daya yang tersedia. Ada beberapa metode yang umum digunakan untuk mengukur efisiensi suatu unit analisis atau biasa disebut dengan Decission Making Unit (DMU). Metode yang umum digunakan adalah Data Envelopment Analysis (DEA).

Data Envelopment Anlysis (DEA) adalah metode non-parametrik yang didasarkan pada teknik pemrograman matematika untuk mengukur tingkat efisiensi dari Decision Making Unit (DMU) atau Unit Pengambil Keputusan (UPK) " relatif" terhadap DMU yang sejenis ketika semua unit-unit ini berada atau di bawah "kurva" efficient frontier-nya. Dengan metode DEA, suatu DMU dikatakan efisien ketika mampu menekan input pada level minimalnya tanpa mengubah jumlah output yang dihasilkan (Input-oriented 
measurement), atau ketika DMU mampu meningkatkan output yang dihasilkan secara proporsional tanpa mengubah jumlah input yang digunakan (Outputoriented Measurement) (Ascarya dan Yumanita (2006:6-8)). Adapun faktor-faktor input dan output yang digunakan dalam mengukur efisiensi kredit atau dianalogikan sebagai pembiayaan pada bank Syariah dijelaskan oleh Bastian, Indra dan Suhardjono (2006: 286-287) adalah Biaya atas penggunaan Dana Pihak Ketiga dan risiko pembiayaan sebagai faktor input serta pendapatan yang didapatkan dari pembiayaan atau kredit sebagai variabel output.

Pengukuran tingkat efisiensi pembiayaan atau kredit pada BUS dan BUK dengan metode Data Envelopment Analysis (DEA) pada dasarnya adalah pengkuran tingkat efisiensi teknis operasional kredit atau pembiayaan yang dalam perhitungannya dapat dilakukan dengan dua asumsi, yaitu asumsi Constan Return to Scale (CRS) dan Variable Return to Scale (VRS). Perbedaan atau gap pada nilai Overall Technical Efficiency (CRS) dan Pure Technical Efficiency (VRS Imenggambarkan tingkat efisiensi skala pembiayaan (Scale Efficiency) suatu bank yang ditunjukkan dengan rasio OTE terhadap PTE .Oleh karena itu pengukuran efisiensi skala pembiayaan (Scale Efficiency) pada BUS dan BUK hanya bisa dilakukan dengan menerapkan dua pengukuran efisiensi yaitu model CRS dan VRS pada saat yang sama.

\section{Rumusan Masalah}

Rumusan masalah dari penelitian ini adalah:

1. Berapakah tingkat efisiensi pembiayaan Bank Umum Syariah dan Bank Umum Konvensional di Indonesia?

2. Apakah terdapat perbedaan efisiensi pembiayaan dengan asumsi CRS pada Bank Umum Syariah dan Bank Umum Konvensional di Indonesia?

3. Apakah terdapat perbedaan efisiensi pembiayaan dengan asumsi VRS pada Bank Umum Syariah dan Bank Umum Konvensional di Indonesia?

4. Apakah terdapat perbedaan efisiensi skala pembiayaan pada Bank Umum Syariah dan Bank Umum Konvensional di Indonesia?

\section{Tujuan Penelitian}

Tujuan dari penelitian ini adalah:

1. Mengetahui tingkat efisiensi pembiayaan pada Bank Umum Syariah dan Bank Umum Konvensional di Indonesia

2. Untuk mengetahui apakah terdapat perbedaan efisiensi pembiayaan dengan asumsi CRS pada Bank Umum Syariah dan Bank Umum Konvensional di Indonesia

3. Untuk mengetahui apakah terdapat perbedaan efisiensi pembiayaan dengan asumsi VRS pada Bank Umum Syariah dan Bank Umum Konvensional di Indonesia

4. Untuk mengetahui apakah terdapat perbedaan efisiensi skala pembiayaan pada Bank Umum Syariah dan Bank Umum Konvensional di Indonesia. 


\section{LANDASAN TEORI}

\section{Pembiayaan Pada Bank Syariah}

Definisi pembiayaan pada Bank Syariah menurut Siamat (2004:183) adalah sistem pembiayaan dengan prinsip Syariah. Pembiayaan berdasarkan prinsip Syariah adalah penyediaan vang atau tagihan yang dipersamakan dengan itu berdasarkan persetujuan atau kesepakatan antara bank dengan pihak ketiga yang mewajibkan pihak ketiga yang dibiayai tersebut untuk mengembalikan vang atau tagihan tersebut dalam jangka waktu tertentu dengan imbalan atau bagi-hasil.

Berdasarkan peraturan Bank Indonesia No. 5/7/PBI/2003, pembiayaan adalah penyediaan dana atau tagihan yang dipersamakan dengan itu berupa:

1. Transaksi Bagi-hasil, yaitu dengan menggunakan prinsip akad: (i) Mudharabah, dan (ii) Musyarakah

2. Transaksi sewa, yaitu dengan menggunakan prinsip akad: (i) ljarah; dan (ii) ljarah Muntahiyah bit-Tamlik

3. Transaksi Jual Beli, yaitu dengan menggunakan prinsip akad: (i) Murabahah; (ii) Salam; dan (iii) Istishna.

4. Transaksi pinjam-meminjam, yaitu dengan menggunakan prinsip akad Qardh, yaitu diaplikasikan pada pelaksanaan akad rahn dan Hiwalah

5. Transaksi multijasa, yaitu dengan menggunakan prinsip akad: (i) ljarah; (ii) Kafalah

\section{Kredit Pada Bank Konvensional}

Definisi kredit menurut UU No.7 Tahun 1992 tentang perbankan sebagaimana telah diubah dengan UU No.10 Tahun 1998 adalah penyediaan vang atau tagihan yang dapat dipersamakan dengan itu, berdasarkan persetujuan atau kesepakatan pinjam-meminjam antara bank dengan pihak lain yang mewajibkan pihak peminjam untuk melunasi utangnya setelah jangka waktu tertentu dengan pemberian bunga.

\section{Analisa Efisiensi Operasional pada Bank}

Pengukuran efisiensi operasional pada bank didasarkan pada aktivitas utama bank sebagai lembaga keuangan yaitu memproduksi jasa penghimpunan dana bagi depositor dan jasa penyaluran dana dalam bentuk kredit pembiayaan dan atau jasa keuangan lainnya kepada kreditor. Pengelolaan kegiatan penghimpunan dan penyaluran dana ini dikatakan efisien ketika bank mampu mendapatkan laba yang maksimal yang bisa dicapai dari kegiatan operasionalnya (Bastian dan Suhardjono,2006:284-286). Adapun jenis-jenis biaya yang dikeluarkan dalam rangka operasional bank, antara lain (Bastian dan Suhardjono, 2006: 284285):

a. Biaya Dana (biaya bunga), yaitu biaya yang dikeluarkan secara langsung dalam rangka penghimpunan dana masyrakat, termasuk di dalamnya biaya promosi, biaya kekurangan dana (loanable fund), dan sebagainya.

b. Biaya Overhead (Overhead cost $\mathrm{OHC}$ ), yaitu biaya yang secara tidak 
langsung dikeluarkan dalam rangka operasional keseluruhan kegiatan bank.

c. Biaya lainnya di luar overhead, yaitu biaya pencadangan aktiva produktif yang dibentuk untuk menutupi risiko kerugian dari aktiva produktif.

Sedangkan pendapatan yang diperoleh bank dari kegiatan operasionalnya adalah:

a. Pendapatan operasional utama (pendapatan bunga).

b. Pendapatan operasional lainnya (pendapatan non-bunga).

\section{Konsep Efisiensi Dalam Perspektif Islam}

Dari sudut pandang ekonomi islam, konsep efisiensi sejalan dengan prinsip Syariah yang bertujuan untuk mencapai dan menjaga maqashid syariah yaitu terpeliharanya al-maal (Kamaruddin,et.al 2008:33). Konsep efisiensi pada dasarnya adalah menghindari segala bentuk pemborosan sebagaimana terkandung dalam surat Al-Israa' ayat 26-27:

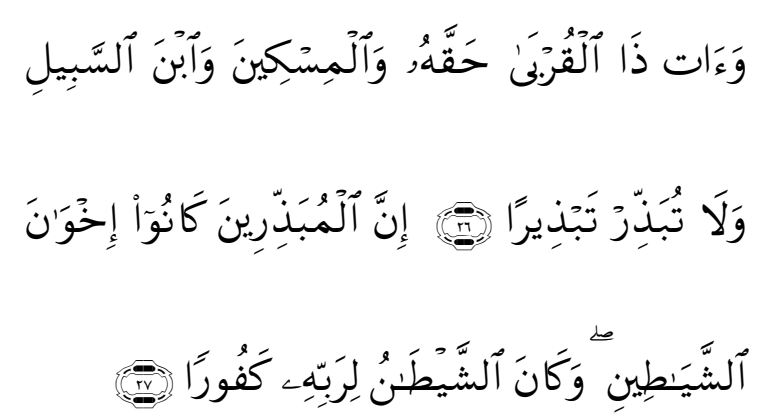

Wa'āti-żalqurbā ḥaqqahu walmiskina wabnassabili walā tubażir tabżīrā. 'innalmubażirīna-kā nū 'ikhwānasysyayā țānu-lirabbihi kafūrā
Artinya: dan berikanlah kepada keluargakeluarga yang dekat akan haknya, kepada orang miskin dan orang yang dalam perjalanan dan janganlah kamu menghambur-hamburkan (hartamu) secara boros. Sesungguhnya pemborospemboros itu adalah saudara-saudara syaitan dan syaitan itu adalah sangat ingkar kepada Tuhannya. (QS.AI-Israa (17):26-27)

Makna kata 'boros' pada ayat di atas adalah berasal dari kata tabdzir yang merupakan kata kerja (fi'il) dari kata sifat (isim) mubadzir yang oleh Imam Syafi'i diartikan sebagai membelanjakan harta tidak pada jalannya. Lebih lanjut dijelaskan oleh Mujahid bahwa walaupun seluruh harta dihabiskan untuk jalan yang benar, maka tidak dikategorikan sebagai mubadzir. Sebaliknya, walaupun hanya segantang padi tapi digunakan untuk hal yang tidak benar maka hal itu disebut dengan mubadzir (Hamka, 2007: 48).

Berdasarkan konsep tersebut di atas, maka konsep efisiensi operasional pembiayaan pada perbankan Syariah merujuk pada keharusan manajemen bank untuk bisa mengelola pengeluaran untuk pos-pos penggerak biaya dengan cara yang tepat guna dan benar, hemat, layak, dan wajar. Hal ini sebagaimana terkandung dalam hadits yang diriwayatkan oleh Ishaq bin Ibrahim Al Handlali telah dikabarkan kepadanya dari Jarir dari Manshur dari Asy Sya'bi dari Warrad bekas budak Al Mughirah bin Syu'bah, dari Mughirah bin Syu'bah dari 
Rasulullah shallallahu 'alaihi wasallam, sesungguhnya Rasulullah shallallahu 'alaihi wasallam bersabda:

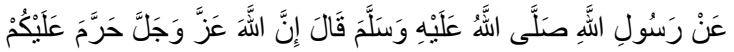

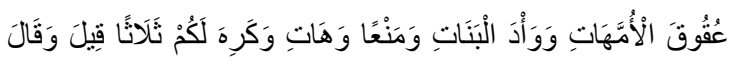

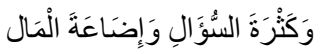

'an rasūlullahu 'alayhi wa sallama qāla innallāha 'azza wa jalla harrama 'alaykum 'vqūqa al'ammahāti wa wa'adalbanāti wa man'awwahāti wa kariha lakum salāisā waqāla wa kasiratassawli wa ị̣̂ā'atalmāl Artinya:"Rasulullah shallallahu 'alaihi wasallam bersabda sesungguhnya Allah 'azza wajalla mengharamkan kalian mendurhakai seorang ibu, mengubur anak perempuan hidup-hidup, dan tidak suka memberi dan suka meminta-minta. Dan membenci atasmu tiga perkara; mengatakan sesuatu yang tidak jelas sumbernya, banyak bertanya dan menyia-nyiakan harta."(HR. Muslim No.3237)

Dimana pada hadits di atas, makna idho'atul maal adalah menggunakannya untuk selain ketaatan kepada Allah atau membelanjakannya secara boros.

\section{Konsep Efisiensi Operasional Pembiayaan pada BUS dan BUK}

Pengukuran efisiensi kegiatan kredit pada bank konvensional atau bisa dianalogikan sebagai kegiatan pembiayaan pada bank Syariah didasarkan pada faktor-faktor operasional bank. Sebagai bagian dari kegiatan pengelolaan dana sebagaimana dijelaskan oleh Bastian, Indra dan Suhardjono dalam buku Akuntansi
Perbankan (2006:286-296), efisiensi dalam pengelolaan dana dapat diukur dengan menggunakan instrumen Biaya dana (Cost of Fund), Cost of Loanable Fund, Rasio biaya overhead, dan produktivitas kredit atau pinjaman. Penggunaan konsep teori tersebut pada perbankan Syariah tentu saja bisa dilakukan dengan melakukan penyesuaian dalam beberapa faktor, yaitu diantaranya penghapusan konsep bunga dalam instrumen biaya dana dan produktivitas kredit/pembiayaan.

\section{Data Envelopment Analysis}

Data Envelopment Analysis (DEA) pertama kali diperkenalkan oleh Charnes, Cooper, dan Rhodes (1978) sebagai metode untuk mengukur efisiensi relatif suatu unit organisasi yang menggunakan multiple input untuk menghasilkan multiple output. Secara garis besar Data Envelopment Analysis (DEA) adalah model pemrograman matematika yang diterapkan pada data observasional. DEA memberikan cara baru estimasi empiris seperti fungsi produksi dan atau efisiensi produksi yang menjadi landasan dalam ekonomi modern.

$$
\text { Dalam perkembangan }
$$

penggunaan metode DEA, ada dua model yang umum digunakan dalam mengukur efisiensi relatif, yaitu model CCR dengan asumsi CRS (Constan Return to Scale) dan BCC dengan asumsi VRS (Variable Return to Scale) (Moussawi dan Obeid,2011:13-14):

1. CCR Model 
Model ini diperkenalkan oleh Charnes, Cooper, dan Rhodes (1978). Asumsi yang digunakan pada model ini adalah Constant Return to Scale (CRS) yang artinya suatu DMU telah berada pada kondisi optimalnya. Sehingga perubahan proporsional pada tingkat input akan menghasilkan perubahan proporsional yang sama pada tingkat output. Jadi bila dilakukan penambahan $1 \%$ input akan menghasilkan penambahan $1 \%$ output. Pengukuran efisiensi dengan model CCR merupakan pengukuran overall technical efficiency (OTE) yang merupakan hasil pengalian antara efisiensi teknis dan efisiensi skala (TE $x$ $\mathrm{SE})$.

2. BCC Model Banker, Charnes, dan Cooper (1984). Asumsi yang digunakan dalam model ini adalah Variable Return to Scale (VRS) yang artinya DMU belum berada pada tingkat optimalnya. Sehingga rasio pada setiap penambahan input dan output tidak sama. sehingga setiap penambahan input sebesar $x$ tidak akan menyebabkan peningkatan pada output sebesar $x$, melainkan bisa lebih kecil atau lebih besar (Moussawi dan Obeid,2011). Pengukuran dengan asumsi VRS akan memisahakan pengukuran efisiensi menjadi dua nilai efisiensi, yaitu Pure Technical Efficiency (PTE) dan efisiensi skala (Scale Efficiency).

Charnes,et.al (1981) dalam Yu (1994) menguraikan bahwa pengukuran efisiensi dengan metode DEA ada dua orientasi yang digunakan, yaitu:

1. Output Orientation (Orientasi output)

2. Input Orientation (Orientasi input)

\section{Hipotesis Penelitian}

Berdasarkan latar belakang, rumusan masalah, tujuan penelitian, landasan teori yang telah dikemukakan maka hipotesis dalam penelitian ini adalah :

$\mathrm{H1}$ : Terdapat perbedaan efisiensi pembiayaan yang signifikan dengan asumsi CRS pada Bank Umum Syariah (BUS) dan Bank Umum Konvensional (BUK) di Indonesia .

H2: Terdapat perbedaan efisiensi pembiayaan yang signifikan dengan asumsi VRS pada Bank Umum Syariah (BUS) dan Bank Umum Konvensional (BUK) di Indonesia .

H3: Terdapat perbedaan efisiensi skala pembiayaan yang signifikan pada Bank Umum Syariah (BUS) dan Bank Umum Konvensional (BUK) di Indonesia .

\section{METODE PENELITIAN}

\section{Pendekatan Penelitian}

pendekatan yang digunakan dalam penelitian ini adalah penelitian kuantitatif. Alat analisis kuantitatif yang digunakan dalam penlitian ini adalah Data Envelopment Analysis (DEA).

\section{Variabel Input}

1. Biaya Dana

Biaya yang telah dikeluarkan sebagai akibat dari penggunaan Dana Pihak Ketiga untuk penempatan dana dalam bentuk kredit atau pembiayaan yaitu berupa biaya 
bunga pada Bank Umum Konvensioanl dan Hak Pihak Ketiga atas Bagi Hasil pada Bank Umum Syariah. Satuan yang digunakan dalam variabel ini adalah jutaan rupiah.

2. Beban PPAP

Terdiri dari beban dari Penyisihan Penghapusan Aktiva Produktif yang merupakan biaya PPAP yang telah digunakan untuk menutupi kerugian aktiva produktif (Bastian, Indra dan Suhardjono,2006:). Satuan yang digunakan dalam variabel ini adalah jutaan rupiah.

\section{Variabel Output}

1. Pendapatan operasional utama

Pendapatan operasional utama dalam hal ini adalah pendapatan bunga/bagi hasil yaitu pendapatan yang didapat dari penempatan dana pada aktiva produktif yaitu pembiayaan dan atau kredit. Pendapatan operasional utama ini yaitu berupa pendapatan bunga kredit pada Bank Umum Konvensional dan penjumlahan pendapatan bagi hasil musyarakah, bagi hasil mudharabah, margin murabahah, dan pendapatan sewa ijarah pada Bank Umum Syariah. Satuan yang digunakan dalam variabel ini adalah jutaan rupiah.

\section{Populasi dan Sampel}

Populasi dalam penelitian ini adalah seluruh Bank Umum Syariah (BUS) dan Bank Umum Konvensional (BUK) yang ada di Indonesia. Pengambilan sampel dalam penelitian ini dilakukan dengan purposive sampling.

\section{Jenis dan Sumber Data}

Data yang digunakan dalam penelitian ini adalah data sekunder. Sedangkan pengumpulan data dalam penelitian ini dilakukan dengan metode kepustakaan atau library research.

\section{Teknik Analisis Data}

1. Data Envelopment Analysis (DEA) Perhitungan nilai efisiensi ini didasarkan pada data-data dari variabel input dan output sebagaimana ditentukan sebelumnya dengan dirumuskan sebagai berikut (Moussawi dan Obeid,2011):

$\max h_{k}=$

$$
r=1 \text { suryrji=1mvixij. }
$$

Dimana:

$h_{k}=$ Nilai efisiensi pembiayan

$u_{r} y_{r j}=$ Output terbobot (Pendapatan operasional utama)

$v_{i} x_{i j}=$ Input terbobot (Biaya dana dan Beban PPAP)

Hasil pengukuran efisinsi pembiayaan dengan model CRS dan VRS akan menghasilkan nilai efisiensi teknis dan efisiensi skala yang dirumuskan sebagai berikut:

$S E=O E / T E$

Dimana:

SE: Scale Efficiency

OE: Overall Efficiency (Model CRS)

TE: Technical Efficiency (Model VRS) 
Pengukuran efisiensi pada penelitian ini akan menggunakan bantuan perangkat aplikasi Data Envelopment Analysis Program (DEAP) 2.1 Version. DMU yang memiliki nilai efisiensi 1 (satu) merupakan DMU yang efisien, sedangkan DMU dengan nilai efisiensi kurang dari 1 (satu) adalah DMU yang tidak efisien. Nilai efisiensi ini merupakan nilai efisiensi relatif antar DMU dengan DMU yang paling efisiensi menjadi benchmark acuan bagi DMU yang lainnya.

2. Uji Hipotesis

Model yang digunakan untuk menguji hipotesis adalah uji beda Mann-Whitney U-Test. Penggunaan model statistik Mann-Whitney U-Test. Jumlah data kelompok sampel I dan kelompok sampel II tidak harus sama; iv. Data berskala ordinal, interval, atau rasio.Perhitungan nilai uji statistik model Mann-Whitney U-Test adalah :

$U_{1_{\text {hitung }}}=$

$n_{1} n_{2} \frac{n_{1}\left(n_{1}+1\right)}{2}-R_{1}$

Atau

$U_{2_{\text {hitung }}}=$

$n_{1} n_{2} \frac{n_{2}\left(n_{2}+1\right)}{2} R_{2}$

Dengan ketentuan bahwa nilai $U_{\text {hitung }}$ Yang diambil adalah nilai $U_{\text {hitung }}$ yang terkecil. Dan untuk memeriksa ketelitian perhitungan digunakan rumus:

$U_{\text {terkecil }}=n_{1} n_{2}-U_{\text {terkecil }}$

Dimana: $\quad U_{1}$ : Statistik uji $U_{1}$ $U_{2}$ : Statistik uji $U_{2}$ $n_{1}$ : jumlah sampel grup sampel yang lebih besar

$n_{2}$ : jumlah sampel grup sampel yang lebih kecil

$R_{1}$ : Jumlah rank sampel grup sampel yang lebih besar

$R_{2}$ : Jumlah rank sampel grup sampel yang lebih kecil

Dalam penelitian ini perhitungan model statistik Mann-Whitney U-Test akan dilakukan dengan menggunakan program aplikasi SPSS 20.

\section{HASIL DAN PEMBAHASAN}

\section{Analisis Komparasi Nilai Efisiensi Model CRS}

Berdasarkan tabel 1 dapat disimpulkan bahwa secara umum Bank Umum Konvensional relatif lebih efisien dengan asumsi Constan Return to Scale (CRS). Sebagaimana terlihat pada tabel 1 bahwa walaupun tidak berbeda terlalu jauh namun terlihat bahwa rata-rata efisiensi dengan asumsi CRS pada Bank Umum Kovensional lebih tinggi dibandingkan dengan rata-rata efisiensi pada Bank Umum Syariah.

Tabel 1.

Perbandingan Nilai Overall Tecnical Efficiency Pada BUS dan BUK

\begin{tabular}{|c|c|c|}
\hline Kelompok Bank & & CRS \\
\hline BUK & mean & 0,674 \\
\hline & $\min$ & 0,211 \\
\hline & max & 1 \\
\hline BUS & SD & 0,203 \\
\hline & mean & 0,629 \\
\hline & min & 0,157 \\
\hline & max & 1 \\
\hline & SD & 0,207 \\
\hline
\end{tabular}


B. Analisis Komparasi Nilai Efisiensi Model VRS

Tabel 2.

Perbandingan Nilai Pure Tecnical Efficiency Pada BUS dan BUK

\begin{tabular}{|c|c|c|}
\hline Kelompok Bank & & VRS \\
\hline BUK & mean & 0,771 \\
\hline & $\min$ & 0,212 \\
\hline & max & 1 \\
\hline & SD & 0,215 \\
\hline BUS & mean & 0,817 \\
\hline & min & 0,437 \\
\hline & max & 1 \\
\hline & SD & 0,199 \\
\hline
\end{tabular}

Berdasarkan tabel 2, secara umum dapat disimpulkan bahwa bahwa secara umum Bank Umum Syariah relatif lebih efisien dalam mengelola faktor input untuk menghasilkan ouput yang optimal. Sebagaimana terlihat pada tabel 4.8, bahwa rata-rata nilai efisiensi pembiayaan dengan asumsi VRS (Pure Technical Efficiency) pada Bank Umum Syariah lebih tinggi dibandingkan dengan rata-rata nilai efisiensi pada Bank Umum Konvensional.

\section{Analisis Komparasi Nilai Efisiensi Skala}

Tabel 3.

Perbandingan Nilai Pure Tecnical Efficiency Pada BUS dan BUK

\begin{tabular}{|c|c|c|}
\hline Kelompok Bank & & Scale \\
\hline BUK & mean & 0,882 \\
\hline & $\min$ & 0,429 \\
\hline & $\max$ & 1 \\
\hline & SD & 0,126 \\
\hline BUS & mean & 0,785 \\
\hline & min & 0,157 \\
\hline & max & 1 \\
\hline & SD & 0,209 \\
\hline
\end{tabular}

Berdasarkan tabel 3 secara umum dapat disimpulkan bahwa Bank Umum
Konvensional memiliki rata-rata nilai efisiensi skala (Scale Efficiency) yang lebih baik bila dengan Bank Umum Syariah.

Hasil ini menunjukkan bahwa secara umum dapat disimpulkan sumber ketidakefisienan pembiayaan pada Bank Umum Syariah lebih dikarenakan ketidakefisienan dalam skala atau size pembiayaan. Hal ini ditunjukkan dengan tingkat Overall Technical Efficiency (CRS) dan Scale Efficiency pada BUS yang lebih rendah bila dibandingkan dengan bank Umum Konvensional, namun pada saat yang sama BUS memiliki tingkat Pure Technical Efficiency (VRS) yang lebih tinggi bila dibandingkan dengan Bank Umum Konvensional.

\section{Uji Normalitas}

Berdasarkan hasil uji normalitas pada tabel 4, dapat disimpulkan bahwa kelompok sampel Bank Syariah maupun Bank Konvensional tidak terdistribusi secara normal karena memilki nilai signifikansi kurang dari nilai $a=0,05$. hanya kelompok Data nilai efisiensi CRS dari kelompok sampel Bank Syariah saja yang terdistribusi secara normal karena memiliki nilai signifikansi lebih dari nilai $a=0,05$. Oleh karena itu, model analisis yang digunakan adalah model non-parametrik independent sampel Mann-Whitney UTest. 
Tabel 4.

Hasil Uji Normalitas

Tests of Normality

\begin{tabular}{|c|c|c|c|c|c|c|c|}
\hline & \multirow[t]{2}{*}{ Kode } & \multicolumn{3}{|c|}{$\begin{array}{c}\text { Kolmogorov- } \\
\text { Smirnova }\end{array}$} & \multicolumn{3}{|c|}{ Shapiro-Wilk } \\
\hline & & Stat & df & Sig. & Stat & df & Sig. \\
\hline \multirow{2}{*}{ CRS } & Bank Konvensional & 099 & 65 & , 187 & 958 & 65 & ,026 \\
\hline & Bank Syariah & 064 & 50 & 200 &, 975 & 50 & 374 \\
\hline \multirow{2}{*}{ VRS } & Bank Konvensional &, 174 & 65 & 000 & 887 & 65 & ,000 \\
\hline & Bank Syariah & 280 & 50 &, 000 & 806 & 50 &, 000 \\
\hline Sca & Bank Konvensional &, 175 & 65 & ,000 & 851 & 65 & ,000 \\
\hline le & Bank Syariah &, 157 & 50 &, 004 & 873 & 50 &, 000 \\
\hline
\end{tabular}

a. Lilliefors Significance Correction

\section{Uji Homogenitas}

Pada Tabel 4 terlihat bahwa untuk kelompok data nilai efisiensi model CRS dan VRS memiliki signifikansi lebih dari $a=0,05$ yang artinya data bersifat homogen yang artinya memiliki varians yang sama, sehingga asumsi homogenitas terpenuhi dan uji hipotesis dengan model statistik Mann-Whitney U-test dapat dilanjutkan. Tetapi untuk kelompok data nilai efisiensi skala (scale efficiency) berdasarkan pada tabel 5 dapat disimpulkan bahwa data tidak homogen karena memiliki signifikansi kurang dari $a=0,05$ yang artinya memiliki varians yang tidak sama sehingga asumsi homogenitas tidak terpenuhi. Oleh karena itu uji statistik Mann-Whitney U-Test tidak dapat dilakukan. Sebagai alternatif maka akan dilakukan uji statistik two independent sample Kolmogorov Smirnov Z-Test yang lebih sensitif pada mean dan varians.
Tabel 5.

Hasil Uji Homogenitas

Test of Homogeneity of Variance

\begin{tabular}{|l|r|r|r|r|}
\hline & $\begin{array}{r}\text { Levene } \\
\text { Statistic }\end{array}$ & df1 & df2 & Sig. \\
\hline Based on Mean &, 045 & 1 & 113 &, 832 \\
Based on Median &, 084 & 1 & 113 &, 772 \\
CRS Based on Median and &, 084 & 1 & 112,88 &, 772 \\
with adjusted df &, 038 & 1 & 113 &, 847 \\
Based on trimmed mean &, 020 & 1 & 113 &, 889 \\
Based on Mean &, 049 & 1 & 113 &, 825 \\
Based on Median &, 049 & 1 & 106,39 & 8 \\
VRS Based on Median and &, 034 & 1 & 113 &, 853 \\
with adjusted df & 11,831 & 1 & 113 &, 001 \\
Based on trimmed mean & 7,373 & 1 & 113 &, 008 \\
Based on Mean & 7,373 & 1 & 85,970 &, 008 \\
Based on Median & 10,721 & 1 & 113 &, 001 \\
\hline
\end{tabular}

Uji Beda Mann-Whitney U-Test

Berdasarkan pada tabel 4.13 dapat diketahui bahwa untuk nilai efisiensi asumsi CRS (Overall Technical Efficiency) memiliki nilai signifikansi 0,270 atau lebih dari nilai $\mathrm{a}=0,05$ yang berarti $\mathrm{HO}$ diterima dan $\mathrm{Hl}$ ditolak. Sehingga dapat disimpulkan bahwa tidak terdapat perbedaan yang signifikan nilai efisiensi kredit/pembiayaan dengan asumsi CRS pada BUS dan BUK. Untuk nilai efisiensi asumsi VRS (Pure Technical Efficiency) memiliki nilai signifikansi 0,206 atau lebih dari nilai $a=0,05$ yang berarti $\mathrm{HO}$ diterima dan $\mathrm{H} \mathrm{l}$ ditolak. Sehingga dapat disimpulkan bahwa tidak terdapat perbedaan yang signifikan nilai efisiensi kredit/pembiayaan dengan asumsi VRS pada BUS dan BUK. Sedangkan untuk nilai scale efficiency nilai signifikansi 0,016 atau kurang dari $a=0,05$ yang berarti $\mathrm{HO}$ ditolak dan $\mathrm{Hl}$ diterima. 
Sehingga dapat disimpulkan bahwa terdapat perbedaan yang signifikan nilai efisiensi skala (scale efficiency) kredit/pembiayaan pada BUS dan BUK.

Tabel 6. Hasil Mann-Whitney U -Test

\begin{tabular}{|c|c|c|c|}
\hline \multicolumn{4}{|c|}{ Test Statistics ${ }^{a}$} \\
\hline & CRS & VRS & Scale \\
\hline Mann-Whitney U & 1429,500 & 1407,000 & 1200,500 \\
\hline Wilcoxon W & 2704,500 & 3552,000 & 2475,500 \\
\hline Z & $-1,104$ & $-1,263$ & $-2,398$ \\
\hline Asymp. Sig. (2-tailed) & 270 & ,206 & .016 \\
\hline
\end{tabular}

\section{G. Uji Beda Kolmogorov-Smirnov Z-Test}

Kelompok data nilai efisiensi skala (Scale Efficiency) tidak memenuhi asumsi homogenitas yang artinya persebaran data tidak sama. Oleh karena itu untuk menguji hipotesis pada kelompok data efisiensi skala (Scale Efficiency), maka akan dilakukan uji ulang dengan menggunakan uji statistik Kolmogorov Smirnov Z-Test.

Berdasarkan tabel 4.14 maka dapat dilihat bahwa nilai signifikansinya adalah 0,023 . Hasil ini kurang dari nilai $a=0,05$, sehingga $\mathrm{HO}$ ditolak yang artinya terdapat perbedaan nilai efisiensi skala (Scale Efficiency) yang signifikan antara Bank Umum Syariah dan Bank Umum Konvensional.

Tabel 7

Hasil Uji Kolmogorov Smirnov Z-Test

Test Statistics ${ }^{a}$

\begin{tabular}{|ll|r|}
\hline & & \multicolumn{1}{|c|}{ Scale } \\
\hline Most Extreme & Absolute &, 282 \\
Differences & Positive &, 000 \\
& Negative &,- 282 \\
Kolmogorov-Smirnov Z & & 1,497 \\
\hline
\end{tabular}

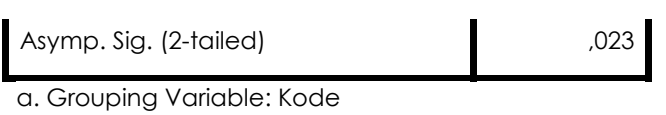

\section{H. Pembahasan Hipotesis}

Hasil uji hipotesis penelitian ini menunjukkan tidak terdapat perbedaan tingkat efisiensi pembiayaan pada BUS dan BUK dengan asumsi VRS. Hal ini menunjukkan bahawa secara murni antara BUS dan BUK pada tingkat ukuran perusahaan yang setara, tidak memiliki perbedaan dalam kemampuan managerial pengelolaan faktor input biaya dana dan beban PPAP menjadi output berupa pendapatan operasional utama. Sedangkan perbedaan tingkat scale efficiency antara BUS dan BUK yang ditunjukan pada hasil pengujian baik Mann-Whitney U-test maupun two independent sample Kolmogorov-Smirnov Z-test pada data nilai scale efficiency menunjukkan bahwa terdapat perbedaan skala ukuran operasional kredit atau pembiayaan antara BUS dan BUK.

Terkait dengan hasil uji beda nilai efisiensi skala tersebut, berdasarkan hasil komparasi nilai rata-rata efisiensi skala (Scale Efficiency) sebagaimana terdapat dalam tabel 4.10 menunjukkan bahwa rata-rata nilai efisiensi skala (Scale Efficiency) Bank Umum Syariah relatif lebih rendah bila dibandingkan dengan nilai Scale Efficiency pada Bank Umum Konvensional. Hasil ini menunjukkan bahwa ketidakefisienan pada pembiayan Bank Umum Syariah lebih dikarenakan ketidakefisienan secara skala atau ukuran 
operasional pembiayaan pada Bank Umum Syariah.

Hasil penelitian ini secara umum mengkonfirmasi situasi yang dihadapi oleh perbankan Syariah saat ini. Saat ini perbankan Syariah tengah mengalami five percent trap, dimana market share perbankan Syariah sulit untuk menembus angka $5 \%$ dari total pangsa pasar industri perbankan Indonesia. Sulitnya mengembangkan pangsa pasar yang dialami perbankan Syariah ini didorong oleh berbagai permasalah strategis baik dari segi pendanaan maupun dari segi pembiayaan. Dari segi pembiayaan, permasalah strategis utama yang menyebabkan perbankan Syariah kesulitan untuk meningkatkan skala usaha pembiayaannya sebagaimana diuraikan dalam laporan perkembangan keuangan Syariah 2013 (diakses pada tanggal 31 Maret 2015) dan diungkapkan oleh Kepala Departemen Perbankan Syariah OJK (sumber: m.beritasatu.com/bank-dan -pembiayaan/288364-ojk-perbankansyariah-hadapi-7-persoalan-strategis.html, diakses pada tanggal 2 Agustus 2015) adalah:

1. Adanya fenomena pajak ganda pada akad pembiayaan bank Syariah yang menyebabkan mahalnya pembiayaan pada Bank Syariah.

2. Terbatasnya modal yang dimiliki oleh bank Syariah sehingga sulit untuk meningkatkan skala usahanya.

3. Rendahnya daya saing bank Syariah di pasar pendanaan, sehingga bank Syariah harus menanggung biaya dana yang tinggi untuk bisa menarik likuiditas dari masyarakat. Situasi ini berimbas pada tingginya beban yang harus ditanggung bank Syariah dan tentu saja juga mendorong bank Syariah untuk menetapkan tingkat margin/fee/bagi hasil yang lebih tinggi.

4. Rendahnya variasi produk pendanaan dan pembiayaan pada bank Syariah yang didorong oleh terbatasnya modal, rendahnya kualitas sumber Daya Manusia (SDM), dan masih rendahnya teknologi informasi yang dimiliki.

\section{SIMPULAN}

Berdasarkan hasil analisis dan interpretasi data yang dilakukan maka dapat diambil kesimpulan sebagai berikut:

1. Bank Umum Syariah memiliki tingkat efisiensi pembiayaan dengan asumsi CRS dan Scale Efficiency yang relatif lebih rendah namun memiliki tingkat efisiensi pembiayaan dengan asumsi VRS yang relatif lebih tinggi bila dibandingkan dengan Bank Umum Konvensional. Hal ini menunjukkan bahwa sumber inefisiensi atau ketidakefisienan pembiayaan pada Bank Umum Syariah adalah karena skala atau Size pembiayaan.

2. Tidak terdapat perbedaan efisiensi pembiayaan dengan asumsi CRS pada Bank Umum Syariah dan Bank Umum Konvensional yang ditunjukkan dengan nilai signifikansi uji beda Mann-Whitney U-Test sebesar 0,270 lebih dari nilai $\mathrm{a}=0,05$ (H1 ditolak) 
3. Tidak Terdapat perbedaan efisiensi pembiayaan dengan asumsi VRS pada Bank Umum Syariah dan Bank Umum Konvensional yang ditunjukkan dengan nilai signifikansi uji beda Mann-Whitney U-Test sebesar 0,206 lebih dari nilai $\mathrm{a}=0,05$ ( $\mathrm{H} 1$ ditolak)

4. Terdapat perbedaan efisiensi skala pembiayaan (Scale Efficiency) pada Bank Umum Syariah dan Bank Umum Konvensional yang ditunjukkan dengan nilai signifkansi uji beda MannWhitney U-Test sebesar 0,16 dan juga nilai signifikansi uji beda kolmogorovSmirnov Z-Test sebesar 0,023 kurang dari nilai $\mathrm{a}=0,05$ ( $\mathrm{H} 1$ diterima)

\section{DAFTAR PUSTAKA}

Arifin, Zainul. 2005. Dasar-Dasar Manajemen Bank Syariah. Jakarta: Pustaka Alvabet

Abidin, Zaenal. 2007. Kinerja Efisiensi Pada Bank Umum. Proceeding PESAT, Vol.2,pp.113-119

Adikara, Yuan Ekananda Muhammad. 2014. Analisis Efisiensi Bank Islam di Inggris Sebelum dan Saat Terjadi Krisis Ekonomi Zona Euro Berdasarkan Data Envelopment Analysis. Skripsi tidak diterbitkan. Surabaya Fakultas Ekonomi dan Bisnis Universitas Airlangga

Antonio, Muhammad Syafi'i.2007. Bank Syariah dari Teori ke Praktik. Jakarta:Gema Insani bekerja sama dengan Tazkia Cendekia

Ascarya dan Yumanita. 2006. Analisis Efisiensi Perbankan Syariah di Indonesia dengan Data Envelopment Analysis. TAZKIA Islamic Finance and Business Review, Vol. 1 (2),pp.1-27

Ascarya dan Yumanita. 2008. Comparing the Efficiency of Islamic Banks in Malaysia and Indonesia. Buletin Ekonomi Moneter dan Perbankan, Vol.11 (2), pp.95-119

Bastian, Indra dan Suhardjono. 2006. Akuntansi Perbankan. Jakarta: Salemba

Cooper, William W, et.al. 2011. Handbook on Data Envelopment Analysis. International Series in Operations Research and Management Sciencei, Vol.124: Chapter

(http://www.springer.com)

Hadad, Muliaman D.,dkk. 2003. Analisis Efisiensi Industri Perbankan Indonesia: Penggunaan Metode Nonparametrik Data Envelopment Analysis (DEA). Buletin Ekonomi dan Perbankan, Vol...(7), pp.1-28

Hamka. 2007. Tafsir Al-Azhar JUz XV. Jakarta:

Hassan, Taufiq, et.al. 2009. Efficiency of Conventional Versus Islamic Banks:Evidence from the Middle East. International Journal of Islamic Middle Eastern and Management, Vol.2(1), pp.46-65

Hidayat, Anwar. 2013. Uji Normalitas Metode Saphiro-Wilk. (http://www.statistikian.com/2013/01/sa phiro-wilk.htmle $m=1$, diakses pada tanggal 9 Mei 2015)

Israel, D. 2010. Data Analysis in Business Research : A Step-by-Step 
Nonparametric Approach. New Delhi:

Vivek Mehra for SAGE Publications India Pvt Ltd.

Jemric, Igor dan Boris Vujcic. 2002. Efficiency of Banks in Croatia: A DEA Approach. Comparative Economic Studies, Vol.44 (2), pp. 169-193

Kamaruddin, Badrul Hisham,et.al. 2008. Assesing Production Efficiency of Islamic Banks and Conventional Bank Islamic Windows in Malaysia. International Journal of Business and Management Science, Vol 1 (1), pp. 31-48

Kristiyanto, Yahuda Eko. 2010. Pengukuran Tingkat Efisiensi Bank-Bank Umum di Indonesia (2000-2007): Aplikasi Data Envelopment Analysis (DEA) dan TOBIT Analysis. Skripsi tidak diterbitkan. Surabaya Fakultas Ekonomi dan Bisnis Universitas Airlangga

Kumar, Sunil dan Rachita Gulati. 2008. An Examination of Technical, Pure Technical, and Scale Efficiencies in Indian Public Sector Banks Using Data Envelopment Analysis. Eurasian Journal of Business and Economics, Vol. 1 (2), pp.33-69

Lind, Douglas A.,et.al. 2007.Teknik-Teknik Statistika dalam Bisnis dan Ekonomi Menggunakan Kelompok Data Global: Buku Satu Edisi Tiga Belas. Jakarta: Salemba Empat

Martic Milan M., et.al. 2009. Data Envelopment Analysis-Basic Models and Their Utilization. Organizacija, Vol.42(2), pp.37-43

Moussawi, Chawki EL dan Hassan Obeid. 2011. Evaluating the Productive
Efficiency of Islamic Banking in GCC: A Non-Parametric Approach. International Management Review, Vol 7(1) pp.10-21

Moussawi, Chawki El dan Hassan Obeid. 2011. Evaluating the Productive Efficiency of Islamic Banking in GCC: A Non-Parametric Approach. International Management Review, Vol.7(1), pp.10-21

Muhamad.2002.Manajemen Bank Syariah. Yogyakarta: Unit Penerbit dan Percetakan (UPP) AMP YKPN.

Muhammad.2005. Manajemen Dana Bank Syari'ah. Yogyakarta: Ekonisia Muharam, H dan Pusvitasari. 2007. Analisis Perbandingan Efisiensi Bank Syariah dengan Metode Data Envelopment Analysis (periode tahun 2005). Jurnal Ekonomi dan Bisnis Islam, Vol.2 No.3

Oberholzer, M dan $G$ Van der Westhuizen. 2004. An Empirical Study on Measuring Efficiency and Profitability of Bank Regions. Meditary Accountancy Research, Vol.12(1), pp.165-178

Otoritas Jasa Kevangan(OJK).2013. Laporan Perkembangan Kevangan Syariah Tahun 2013. (http://www.ojk.go.id/publikasilaporan-perkembangan-keuanganSyariah-2013, diakses pada tanggal 22 Januari 2015)

Otoritas Jasa Keuangan(OJK).2015. Statistik Perbankan Syariah Januari 2015. (http://www.ojk.go.id/statistikperbankan-Syariah-januari-2015, diakses pada tanggal 22 Januari 2015) 
Pratikno, Heri dan lis Sugianto. 2011. Kineja Efisiensi Bank Syariah Sebelum dan Sesudah Krisis Global Berdasarkan Data Envelopment Analysis. Jurnal Ekonomi Bisnis, Vol.16(2), pp.108-117

Qureshi, Muhammad Azeem dan Madeeha Shaikh. 2012. Efficiency of Islamic and Conventional Banks in Pakistan: A Non-Parametric Approach. International Journal of Business and Management, Vol.7(7), pp.40-50

Sherman, H.D dan Zhu,J. 2006. Service Productivity Management Improving Service Performance Using Data Envelopment Analysis (DEA) (http://www.springer.com/978-0-387-

33211-6)

Siamat, Dahlan. 2004. Manajemen Lembaga Keuangan: Edisi keempat. Jakarta: Lembaga Penerbit Fakultas Ekonomi Universitas Indonesia

Subaweh, Imam. 2008. Analisis Perbandingan Kinerja Keuangan Bank Syariah dan Bank Konvensional Periode 2003-2007. Jurnal Ekonomi Bisnis, Vol 13(2), pp.112-121

Sudarsono, Heri. 2007. Bank dan Lembaga Kevangan Syaria'ah: Deskripsi dan Ilustrasi. Condongcatur: Ekonosia

Thanassoulis, Emmanuel. 1999. Data Envelopment Analysis and Its Use in Banking. Institute for Operations Research and The Management Sciences, Vol.29(3), pp.1-13

Yu, Hong Cynthia. 1997. Financial Efficiency Analysis: A DEA Approach. Thesis diterbitkan oleh UMI 